\title{
Regulation of Angiogenesis in Choroidal Neovascularization of Age Related Macular Degeneration by Endogenous Angioinhibitors
}

\author{
Venugopal Gunda ${ }^{1}$ and Yakkanti A. Sudhakar ${ }^{1,2}$ \\ ${ }^{1}$ Cell Signaling, Retinal and Tumor Angiogenesis Laboratory, \\ Department of Genetics, Boys Town National Research Hospital, Omaha, NE, \\ ${ }^{2}$ Department of Biochemistry and Molecular Biology, \\ University of Nebraska Medical Center, Omaha, NE,
}

USA

\section{Introduction}

The sense of vision has utmost significance and the loss of vision leads to the impairment of active human behavior as evident in pathological disorders that affect vision. Among different pathological visual disorders, Age Related Macular Degeneration (AMD/ARMD) is of serious concern as a leading cause of blindness, observed with aging globally. The clinical manifestation of AMD includes retinal damage with the degeneration of macula, leading to the partial or complete loss of acuity in vision. One form of pathologic AMD named, "wet form of AMD", involves the growth of new blood vessels from the choroid which lies underneath the retina, leading to the pathological blood vessel growth termed as Choroidal Neovascularization (CNV), with subsequent damage to the retina. Thus, choroidal neovascularization reflects a pathological angiogenic condition, where the loss of regulation over angiogenesis leads to the retinal damage. It also indicates that, the regulation of pathological angiogenesis can be an efficient strategy in preventing CNV of AMD. Though, some genetic disposition and aging factors are identified as peculiar etiological factors causing AMD; recent studies have shown that different cellular mechanisms regulating angiogenesis are common in different angiogenic scenarios including CNV. Further, the role of different endogenous angiogenesis inhibitors/angioinhibitors conferring the tissues with angiogenic regulation has been deciphered, which can be applied for regulation of CNV in AMD through inhibition of angiogenic signaling mechanisms. The present chapter provides an overview of the role of factors leading to choroidal neovascularization, the mechanisms underlying such angiogenesis and also the scope for endogenous angioinhibitors in regulation of CNV of AMD.

\subsection{Retina and choroid}

Retina is the inner most layer of the eye, which possesses anatomically ten distinct layers that are broadly categorized into two layers. The inner neural layer comprising of extensive 
nervous tissue towards the vitreous chamber and the outer retinal pigmented epithelium (RPE) adhering to the choroid. Some of the functions of the RPE include the phagocytosis of outer retinal segmental discs, maintenance of chorio-capillaries, fluid and electrolyte balance in subretinal space. Choroid is the highly vascular and pigmented tissue of the eye lying between the retina and the sclera. It consists of lamina suprachoroidea adhering to sclera, followed by lamina vesculosa, chorio-capillaries, stroma and Bruch membrane adhering to the RPE. Choroid is rich in vasculature and the extracellular matrix (ECM) components, including collagen and elastin fibers. It provides nutrient, metabolite and gaseous exchange to the retina by diffusion through chorio-capillaries.

\subsection{Choroidal neovascularization in age related macular degeneration}

The histological proximity between retinal pigmented epithelium and choroid confers not only physiological but also pathological effect on RPE. The mechanical barrier that separates the RPE from choroid is the Bruch membrane, which in turn consists of basement membrane secreted by RPE, inner collagenous layer, elastic layer, outer collagenous zone and the basement membrane of chorio-capillaries acting as a mechanical barrier for the underlying chorio-capillaries, but facilitating diffusion of metabolites and gaseous exchange for RPE. In cases of $\mathrm{CNV}$ the Bruch membrane is distorted with initial deposition of lipid and protienaceous component called 'drusen' followed by the growth and penetration of blood capillaries from choroid into Bruch membrane, finally leading to the leakage of fluid into sub-retinal spaces and retinal or retinal pigmented epithelial damage (Green, 1999; Green and Enger, 1993; Jager et al., 2008).

\subsection{Factors for choroidal neovascularization in age related macular degeneration}

Pathological neovascularization in CNV of AMD is considered to be contributed by both the angiogenesis and vasculogenesis, which are the processes of de-novo blood vessel formation (Chan-Ling et al., 2011; Jager et al., 2008). Angiogenesis is the process of formation of new blood vessels from the pre-existing ones, which involves the role of different cell types and remodeling of ECM. The inception of different cell types involved in the angiogenesis, such as, the endothelial cells (ECs) of RPE and choroid involved in CNV, mural cells and inflammatory cells occurs through vasculogenesis, by the differentiation of endothelial progenitor cells (EPCs). The EPCs found in the normal circulation are recruited into angiogenic sites, where they differentiate into different cell types leading to angiogenesis (Chan-Ling et al., 2011; Jager et al., 2008). However, the salient feature of neovascularization involves the common sequential events of angiogenesis including the proliferation of ECs, degradation of ECM or vascular basement membrane (VBM) by ECs through secretion of proteases, migration and differentiation of ECs into tip and stalk cells, lumen development, ECM reorganization and finally vessel anastomosing into functional capillaries (Carmeliet and Jain, 2000). These sequential steps of angiogenesis are considered to be common for $\mathrm{CNV}$, which are initiated by the release of angiogenic factors by the RPE and other cell types differentiated from EPCs or infiltrating through the leaky capillaries in response to aging evoked stress (Alon et al., 1995; Grossniklaus et al., 2002). The initiating cellular and physiological factors that lead to the secretion of angiogenic factors by ECs and other cell types have been identified in different studies, which can be systematically framed for synergistic interpretation of etiological factors leading to CNV. 
The normal function of phagocytosis and degradation of phagocytosed membranes is impaired with aging in RPE, leading to the accumulation of lipofuscin in these cells, with senescence (Marshall, 1987; Young and Bok, 1969). Ischemia and hypoxia evident in the ocular tissues of $\mathrm{CNV}$ are identified as factors promoting free radical generation in RPE and also the release of cellular lipids and proteinaceous deposits into the Bruch membrane (Spaide et al., 2003). Thus, impairing Bruch membrane's barrier function and in turn leading to the secretion of different angiogenic factors like vascular endothelial growth factor (VEGF), transforming growth factor- $\beta$ (TGF- $\beta$ ), basic fibroblast growth factor (bFGF), insulin-like growth factor-1 and platelet derived growth factor (PDGF) by the RPE and the macrophages and stromal cells that are recruited by the differentiation of EPCs (Alon et al., 1995; Grossniklaus et al., 2002; Lu and Adamis, 2006; Penn et al., 2008; Young and Bok, 1969). Damage to the Bruch membrane is considered to enhance the diffusion of the growth factors, which elicit angiogenic signaling in the ECs (Lu and Adamis, 2006; Marshall, 1987; Penn et al., 2008).

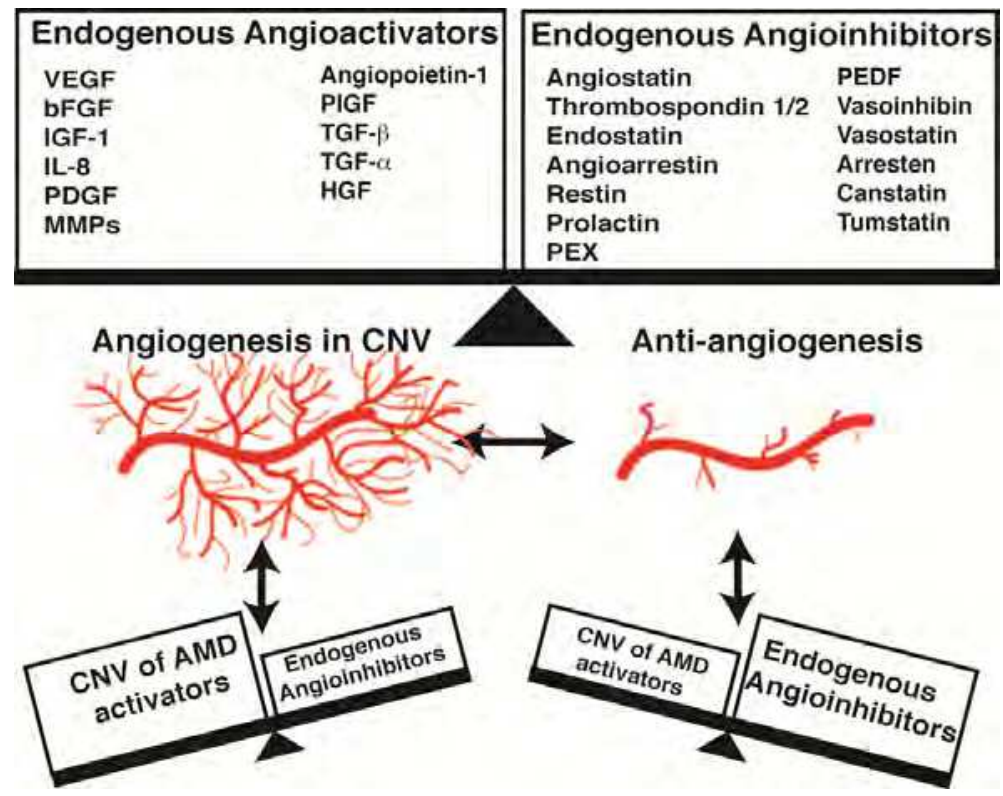

Fig. 1. The angiogenic balance between endogenous angioactivators and angioinhibitors regulate vascular homeostasis. Angiogenesis under physiological and pathological conditions is associated with up-regulation of endogenous angioactivators and/or downregulation of endogenous angioinhibitors. Up-regulation of angioinhibitors and/or downregulation of angioactivators may be associated with impaired neovascularization capacity in the choroidal neovascularization in age related macular degeneration (CNV of AMD). VEGF, vascular endothelial growth factor; bFGF, basic fibroblast growth factor; IGF-I, insulin-like growth factor-I; IL-8, interleukin-8; PDGF, platelet-derived growth factor; PlGF, placental growth factor; TGF- $\alpha$ and $\beta$, transforming growth factor- $\alpha$ and $\beta$;

HGF, Hepatocyte growth factor 


\begin{tabular}{|l|l|l|}
\hline $\begin{array}{l}\text { Endogenous } \\
\text { Angioactivators }\end{array}$ & Potent Receptors & Angiogenic action \\
\hline $\begin{array}{l}\text { Vascular endothelial } \\
\text { growth factor (VEGF) \& } \\
\text { Placental growth factor } \\
\text { (PlGF) }\end{array}$ & $\begin{array}{l}\text { VEGFRs (Flt-1, Flk-1, } \\
\text { KDR, Flt-4), } \\
\text { Neuropilins, HSPG, } \\
\text { integrins }\end{array}$ & $\begin{array}{l}\text { Increases EC permeability, proliferation, migration, } \\
\text { NO, uPA/PAI-1 \& MMP production } \\
\text { Inhibiting EC apoptosis, } \\
\text { Promotes ECM degradation } \\
\text { Monocyte migration }\end{array}$ \\
\hline $\begin{array}{l}\text { Transforming growth } \\
\text { factor- } \beta \text { (TGF- } \alpha,-\beta)\end{array}$ & $\begin{array}{l}\text { Transforming growth } \\
\text { factor receptors }\end{array}$ & $\begin{array}{l}\text { Increased vessel stability and organization, promote } \\
\text { secretion of ECM components }\end{array}$ \\
\hline $\begin{array}{l}\text { basic Fibroblast growth } \\
\text { factor (bFGF) }\end{array}$ & $\begin{array}{l}\text { FGFRs, HSPG, } \\
\text { integrins }\end{array}$ & $\begin{array}{l}\text { Promotes EC proliferation, migration, tube } \\
\text { formation, ECM degradation, vessel maturation }\end{array}$ \\
\hline $\begin{array}{l}\text { Insulin-like growth } \\
\text { factor-1 (IGF-1) }\end{array}$ & $\begin{array}{l}\text { Insulin-like growth } \\
\text { factor receptors }\end{array}$ & $\begin{array}{l}\text { Promotes EC migration, proliferation, tube } \\
\text { formation }\end{array}$ \\
\hline $\begin{array}{l}\text { Platelet derived growth } \\
\text { factor (PDGF) }\end{array}$ & $\begin{array}{l}\text { PDGF- } \alpha,-\beta, \text { GPCRs, } \\
\text { integrins }\end{array}$ & Increases EC permeability, proliferation, migration \\
\hline Angiopoietin-1 & Tie-2, integrins & EC sprouting, Vessel stabilization \\
\hline $\begin{array}{l}\text { Hepatocyte growth factor } \\
\text { (HGF) }\end{array}$ & $\begin{array}{l}\text { Hepatocyte growth } \\
\text { factor receptor }\end{array}$ & Promotes tubulogenesis along with other factors \\
\hline Interleukin-8 (IL-8) & $\begin{array}{l}\text { C-X-C chemokine } \\
\text { receptor type (CXCR- } \\
1,2)\end{array}$ & $\begin{array}{l}\text { Activates neovascularization increasing } \\
\text { invasiveness of different cell types }\end{array}$ \\
\hline $\begin{array}{l}\text { Matrix } \\
\text { metalloproteinases } \\
\text { (MMPs) }\end{array}$ & $\begin{array}{l}\text { Degradation of ECM components promoting EC } \\
\text { migration and vessel organization, release of ECM } \\
\text { or cell surface bound/sequestred angiogenic fcators }\end{array}$ \\
\hline
\end{tabular}

Table 1. Endogenous activators, their receptors and angiogenic activities (EC: endothelial cell, ECM: extracellular matrix, FGFRs: Fibroblast growth factor receptors, Flk-1: Fetal liver kinase-1, Flt-1, 4: fms-related tyrosine kinase, GPCRs: G-protein coupled receptors, HSPG: Heparan sulfate proteoglycan, KDR: kinase insert domain receptor, MMP: matrix metallo proteinase, NO: nitric oxide, Pak: p21 protein activated kinase, PDGF: platelet derived growth factor, Tie: tyrosine kinase with immunoglobulin-like and EGF-like domains, VEGFRs: vascular endothelial growth factor receptors)

The integrins and other ECM binding receptors present on ECs are essential in maintaining the ECM promoted survival and migration in angiogenesis (Avraamides et al., 2008; Mettouchi and Meneguzzi, 2006). The synergistic activation of integrins and other ECM binding receptors on ECs by the growth factors and cytokines leads to the activation of different signaling cascades mediated by the kinases, secondary messengers, transcription factors such as, nuclear factor kappa $\beta$ (NF-k $\beta$ ), hypoxia inducible factor- $1 \alpha$ (HIF-1 $\alpha$ ), and other enzymes such as, inducible nitric oxide synthase (iNOS), cyclooxygenase-2 (COX-2) and metalloproteinases (MMPs) (Avraamides et al., 2008; Boosani et al., 2007; Egeblad and Werb, 2002; Mettouchi and Meneguzzi, 2006; Oklu et al., 2010). The transcription factors that are stabilized, up-regulated or expressed under hypoxia also lead to activation of different signaling cascades that promote effective survival and proliferation of ECs. The secretion of proteases such as matrix metallo-proteinases (MMPs) including collagenases and elastases, which degrade the collagen and elastin of vascular basement membrane (VBM) promote the migration of ECs. The urokinase is another proteinase, which binds to its receptors (urikanse binding receptor, $\mathrm{uPAR}$ ) and activates signaling cascades leading to the secretion of MMPs, which promote migration of ECs and angiogenesis. The organization and differentiation of 
migrating ECs into tip and stalk cells is further enumerated to be regulated by Wingless type (Wnt)/Frizzled-Notch signaling that provides an insight about formation of functional capillaries in neovascular vessels (Dejana, 2010; Zerlin et al., 2008).

The inflammatory cells that are recruited through the expression of cytokines such as monocyte chemo-attractant protein-1 (Ccl2/MCP-1), Chemokine (C-X-C motif) liagnd 1 (CXCL1), macrophage inflammatory protein-1/-2 (MIP-1, MIP-2) are also considered to play role in CNV progression (Hendricks, 2006). Further, the intriguing stimulative role of Bruch membrane in promoting AMD is also being deciphered by identifying the complement components $3 \mathrm{a}$ and $5 \mathrm{a}(\mathrm{C} 3 \mathrm{a}$ and $\mathrm{C} 5 \mathrm{a})$, which lead to the up-regulation of VEGF-A (Nozaki et al., 2006). Thus, the orchestration of various signaling events at different stages of angiogenesis leads to the neovascularization. The angiogenic ECs lining the neovascular vessels arising due to the above factors in $\mathrm{CNV}$ are found to possess fenestrations and also organize into defective capillaries leading to the leakage of macromolecules as well as vascular cells into the Bruch membrane and sub-retinal spaces leading to the degeneration of macula of retina (Dvorak et al., 1995; Roberts and Palade, 1995).

\section{Endogenous angioinhibitors}

In addition to the angiogenic factors, which activate angiogenesis, tissues and ECM also possess angioinhibitors, which have the potency to inhibit the angiogenesis and thus, regulating the pathological angiogenesis by inhibiting the signaling mechanisms activated by angiogenic factors (Boosani et al., 2010; Sudhakar and Kalluri, 2010, Zhang and Ma, 2007). Nearly, 40 endogenous angioinhibitors have been characterized and some of them are found in the ocular tissues or secreted into vasculature and released into ocular tissues, where they exhibit angio-inhibition and finally regulation of CNV (Boosani et al., 2011; Sudhakar and Kalluri, 2010). The significance of imbalance in the levels of endogenous angioinhibitors and angioactivators in regulation of vascular homeostasis can be summarized as in Figure 1. This significance was also ascertained by the evaluations showing the correlation between the decrease in specific angioinhibitors and the progression of CNV (Bhutto et al., 2008).

\subsection{Mechanisms of regulation of CNV by endogenous angioinhibitors}

\subsubsection{Vasoinhibins}

The vasoinhibins (14-18 $\mathrm{kDa}$ ) are antiangiogenic peptides found in the pituitary, retina and extrapituitary tissues. They constitute the amino terminal regions of three different precursors; prolactin, growth hormone and placental lactogen. Though their precursors do not exhibit angioinhibitory activities; vasoinhibins found in the tissues or those expressed using recombinant methods exhibit antiangiogenic properties (Clapp et al., 2008). The therapeutic potential of vasoinhibins in regulating angiogenesis in $\mathrm{CNV}$ and tumor growth was evaluated and studies indicate that adenovirus mediated expression of vasoinhibins inhibits CNV, in-vivo and also angiogenesis (Zhou et al., 2010). Mechanisms of regulation of EC survival, proliferation and migration by the vasoinhibins have been deciphered in different studies; nevertheless, the receptors through which the mechanisms are mediated still remain enigmatic. Vasoinhibins regulate the EC migration and survival through inhibition of VEGF and bFGF stimulated MAPK activation (D'Angelo et al., 1995). 


\begin{tabular}{|c|c|c|c|}
\hline \begin{tabular}{|l|} 
Endogenous \\
Angioinhibitor \\
\end{tabular} & Parent molecule & Receptors & $\begin{array}{l}\text { Mode of action/ Inhibition } \\
\text { pathways }\end{array}$ \\
\hline Vasoinhibins & $\begin{array}{l}\text { Prolactin, growth } \\
\text { hormone }\end{array}$ & Not known & $\begin{array}{l}\text { Sos/Ras/MAPK or eNOS } \\
\text { /Raf/MAPK, Ca2+/ eNOS/protein } \\
\text { phosphatase 2, Ras/Tiam- } \\
\text { 1/Rac1/Pak1, Bcl-XL, NF-k } \beta \text {, } \\
\text { caspases }\end{array}$ \\
\hline PEDF & PEDF & Not known & Possible apoptosis \\
\hline Arresten & $\begin{array}{l}\text { Collagen IV, } \\
\alpha 1 \text { NC1 }\end{array}$ & $\alpha 1 \beta 1$ integrin, HSPG & $\begin{array}{l}\text { Raf/MEK/ERK1/2/p38-MAPK, } \\
\text { HIF-1 } \alpha, \text { MMPs }\end{array}$ \\
\hline Canstatin & $\begin{array}{l}\text { Collagen IV, } \\
\alpha 2 \mathrm{NC1}\end{array}$ & $\begin{array}{l}\alpha \mathrm{V} \beta 3, \alpha \mathrm{V} \beta 5 \\
\text { integrins, Fas }\end{array}$ & $\begin{array}{l}\text { procaspse- } 8 \text { and }-9, \text { Akt/ } \\
\text { FAK/mToR, eIF-4EBP-1, } \\
\text { Ribosomal S6-kinase }\end{array}$ \\
\hline Tumstatin & $\begin{array}{l}\text { Collagen IV, } \\
\text { a3NC1 }\end{array}$ & $\begin{array}{l}\text { CD47/IAP, } \alpha V \beta 3, \\
\alpha 6 \beta 1 \text { integrins } \\
\end{array}$ & $\begin{array}{l}\text { FAK/Akt/PI3K/mTOR/ } \\
\text { eIF-4EBP1/NFkB, COX-2 signaling }\end{array}$ \\
\hline Endostatin & $\begin{array}{l}\text { Collagen } \\
\text { XVIII-NC1 }\end{array}$ & $\begin{array}{l}\alpha \mathrm{V} \beta 1 / \alpha 5 \beta 1 \\
\text { integrins, } \\
\text { HSP, glypican, } \\
\text { caveolin-1 } \\
\end{array}$ & $\begin{array}{l}\text { Ras/Raf/KDR/Flk-1 / ERK/p38- } \\
\text { MAPK/p125 } \\
\text { FAK/HIF1 } \alpha / \text { Ephrin/TNF } \alpha / N F \kappa B, \\
\text { Wnt signaling }\end{array}$ \\
\hline Angiostatin & Plasminogen & $\begin{array}{l}\text { ATP synthases, } \alpha \mathrm{V} \beta 3 \\
\text { integrin, angiomotin }\end{array}$ & $\begin{array}{l}\alpha V \beta 3 \text { integrin mediated apoptotis, } \\
\text { ATP synthase }\end{array}$ \\
\hline Thrombospondins & TSP & $\begin{array}{l}\text { CD36, IAP, CD47, } \\
\text { HSPG, a3 } \beta 1, \text { other } \\
\text { integrins }\end{array}$ & \begin{tabular}{|l|} 
Src-family kinases/ \\
Caspase-3/p38 MAPK, \\
TGF- $\beta$ signaling \\
\end{tabular} \\
\hline Endorepellin & Perlecan & $\begin{array}{l}\text { a2 } \beta 1 \text { integrins, lipid } \\
\text { rafts, caveolin }\end{array}$ & $\begin{array}{l}\text { cAMP-PKA/FAK/p38- } \\
\text { MAPK/Hsp27, } \\
\text { SHP-1, Ca2+ signaling }\end{array}$ \\
\hline
\end{tabular}

Table 2. Endogenous angioinhibitors, their precursors, cell surface receptors and mode of action AMD/ARMD: Age related macular degeneration, Akt: protein kinase B, Bcl-XL: B-cell lymphoma-extra large, bFGF: basic fibroblast growth factor, Ccl2/MCP-1: chemoattractant protein-1, $\mathrm{CD}(\mathrm{CD} 47, \mathrm{CD} 36)$ : cluster of differentiation, $\mathrm{CNV}$ : choroidal neovascularization, COX-2: cyclooxygenase-2, eIF-4EBP-1: eukaryotic translation initiation factor-4E binding protein-1, eNOS: endothelial nitric oxide synthase, ECs: endothelial cells, ECM: extracellular matrix, EPCs: endothelail progenitor cells, ERK1/2: extracellular signal-regulated kinase1/2, FAK: focal adhesion kinase, Flk-1: fetal liver kinase-1, HIF-1 $\alpha$ : hypoxia inducible factor$1 \alpha$, Hsp: heat shock protein, HSPG: Heparan sulfate proteoglycan, IAP: integrin associated protein, KDR: kinase insert domain receptor, MAPK: Mitogen activated protein kinase, MEK: MAPK-ERK kinase, MMPs: matrix metallo proteinases, mToR: mammalian target of rapamycin, NF-k $\beta$ : nuclear factor kappa $\beta$, Pak: p21 protein activated kinase, PDGF: platelet derived growth factor, PEDF: Pigment epithelium derived factor, PEX: noncatalytic Carboxyterminal hemopexin-like domain of MMP, PI3K: phosphatidyl inositol 3-kinase, Rac: Ras-related C3 botulinin toxin susbtrate 1, Raf: Ras activated factor, Ras: Rat sarcoma, RPE: retinal pigmented epithelium, SHP: Src homology region 2 domain-conatining phopshatase, Sos: Son of sevenless, Src: Schmidt-Ruppin A-2 sarcoma viral oncogene homolog, Tiam: T-lymphoma invasion and metastasis-inducing protein, TGF- $\beta$ : transforming growth factor $\beta$, TNF $\alpha$ : tumor necrosis factor $\alpha$, TSP: thrombospondin, VBM: vascular basement membrane, VEGF: vascular endothelial growth factor, Wnt: wingless-type 
VEGF activated Sos/Ras/MAPK or eNOS/Raf/MAPK-mediated proliferative signaling and $\mathrm{Ca} 2+/ \mathrm{eNOS} /$ protein phosphatase-2 mediated vascular permeability and vasodilatation were shown to be inhibited by the vasoinhibins (Gonzalez et al., 2004; Ziche and Morbidelli, 2000). In addition vasoinhibins also inhibit the migration of EC stimulated by IL-1 $\beta$ through Ras/Tiam-1/Rac-1/Pak1 and promote apoptosis through conversion of Bcl-XL to proapoptoctic Bcl-Xs and NF-k $\beta$ mediated activation of initiator and effector caspases (Martini et al., 2000; Tabruyn et al., 2003).

\subsubsection{Pigment Epithelium Derived Factor (PEDF)}

Pigment epithelium derived factor (PEDF) is a $50 \mathrm{kDa}$, secreted, serpin family glycoprotein, first identified from the cultured fetal RPE conditioned media (TombranTink et al., 1991). PEDF accumulates in the vitreous humor and is also expressed in different adult tissues (Tombran-Tink et al., 1991). Addition of PEDF to the cultured HUVECs increased the number of TUNEL positive cells suggesting apoptotic mode of action of PEDF and thus, possibly preventing EC response to ischemia in-vivo (Ho et al., 2007). The levels of PEDF were found to be decreased in Bruch membrane with progression of AMD and concomitant increase in VEGF levels were also identified with decrease in PEDF levels (Bhutto et al., 2008). Different methods of PEDF upregulation have been applied to investigate the effect of PEDF on CNV. Intravitreous injections of adenovirus expressing the PEDF and ultrasound-microbubble technique of noninvasive gene transfer of PEDF gene in rats exhibited significant decrease in the CNV (Gehlbach et al., 2003; Zhou et al., 2009). However, studies also demonstrate that PEDF at lower doses $(90 \mu \mathrm{g} / \mathrm{ml})$ has negative effect on CNV whereas; higher doses (2-4 fold) can augment CNV; thus, indicating a strategic approach to be developed during clinical trials for $\mathrm{CNV}$ treatment with PEDF (Apte et al., 2004).

\subsubsection{Angiostatin}

Angiostatins are 38-45 kDa kringle domains derived by the protease activity of parent molecule plasminogen, which itself has significant role in activation of fibrinogen and blood clotting (Hayashi et al., 2008). Some of the angiostatin peptide derivates exhibit antiangiogenic properties including inhibition of EC proliferation, tube formation and migration. The application of angiostatins in regulating CNV of AMD was evaluated by the expression of the angiostatins in-vivo, using viral vectors (Lai et al., 2001). Angiostatins bind to ATP synthases on the surface of ECs leading to their apoptotic death (Burwick et al., 2005; Tarui et al., 2001). Further $\alpha \mathrm{V} \beta 3$ integrin and angiomotin are also shown to bind angiostatin and induce apoptosis (Burwick et al., 2005; Tarui et al., 2001).

\subsubsection{Thrombospondins}

Thrombospondins (TSPs) are secreted ECM glycoproteins playing key role in the cellular and ECM interactions (Bornstein, 2001; Lawler, 2000). The NH2-terminal peptides derived from the TSPs, by the action of different proteases are identified to possess angioinhibitory properties. TSP-1 and TSP-2 are trimeric globular domain subunits (145 kDa) categorized into subgroup-A and subgroup-B consists of TSP's 3-5, which are pentameric subunits (110 $\mathrm{kDa}$ ) (Bornstein, 2009). TSP-1 was the first identified ECM derived endogenous 
angioinhibitor from many normal tissues and produced by a variety of cells including platelets, megakaryocytes, epithelial, endothelial and stromal cells (Bornstein, 2009). TSP-1 is secreted by the retinal-pigmented epithelium (RPE) and regulates angiogenesis in normal eye (Miyajima-Uchida et al., 2000). Immunolocalization studies showed decrease in the levels of TSP in the chorio-capillaries and the Bruch membrane of AMD samples (Bhutto et al., 2008). Wispostatin-1 (WISP-1) repeat derived peptide from TSP-1 was shown to inhibit the CNV in LASER induced CNV mice models (Cano Mdel et al., 2009). TSP-1 induces apoptosis in ECs through CD36 and integrin associated protein (IAP)/Src-family protein kinases/Caspase-3/p38 MAPK signaling (Dawson et al., 1997). In addition TSP-1 can also bind to different integrins, including CD47 and heparin sulfated proteoglycans (Kaur et al., 2011). Thus the significance of TSPs in regulation of CNV have been evaluated through detection of endogenous levels in pathological tissues and also by evaluating the effects of TSPs both in vitro and in vivo.

\subsubsection{Arresten}

Arresten $[\alpha 1(\mathrm{IV}) \mathrm{NC} 1]$, is the $26 \mathrm{kDa}$ collagen type IV, $\alpha 1$ chain derived non-collagenous domain, which functions via binding to a1 $\beta 1$ integrin and heparan sulfate proteolgycans, regulating bFGF and VEGF stimulated activation of ECs (Boosani and Sudhakar, 2006; Colorado et al., 2000; Sudhakar et al., 2005). It inhibits the survival of mouse lung endothelial cells through inhibition of FAK phopshorylation in AKT independent manner (Sudhakar et al., 2005). FAK inhibition by arresten via $\alpha 1 \beta 1$ integrin leads to inhibition of downstream Raf/MEK/ERK1/2/p38 MAPK signaling and HIF-1 $\alpha$ expression (Figure 2). Inhibition of HIF-1 $\alpha$ by arresten is critical in preventing hypoxic survival of ECs through VEGF regulation (Sudhakar et al., 2005). Arresten inhibited VEGF-mediated angiogenesis by promoting apoptosis, caspase-3/PARP activation and negatively impacting FAK/p38MAPK phosphorylation, $\mathrm{Bcl}-2$ and $\mathrm{BCl}-\mathrm{x}_{\mathrm{L}}$ expressions leading to mouse retinal endothelial cell (MREC) death (Boosani et al., 2009). In addition angioinhibitory activity of arresten was found to inhibit bFGF induced proliferation of MREC in-vitro in a dose dependent manner. It also inhibited the bFGF-induced migration of MREC mediated by MMP-2 activity but not the expression levels of MMP-2 (Boosani et al., 2010). Thus, arresten was shown to effect the proliferation and migration of choroidal endothelial cells and regulate CNV of AMD. The endothelial specific inhibitory actions of arresten may be of benefit in the treatment of a variety of eye diseases with a neovascular component.

\subsubsection{Canstatin}

It is the $24 \mathrm{kDa}$ collagen type IV, $\alpha 2$ derived non-collagenous domain [ $\alpha 2(\mathrm{IV}) \mathrm{NC} 1]$, which binds to the $\alpha \mathrm{V} \beta 3$ and $\alpha \mathrm{V} \beta 5$ integrins and inhibits EC proliferation, migration and tube formation by enhancing apoptosis in these cells (Magnon et al., 2005; Magnon et al., 2007; Petitclerc et al., 2000; Roth et al., 2005). The antiangiogenic efficacy of canstatin in regulating the neovascularization of cornea was also evaluated using the recombinant canstatin in alkali burn induced neovascularization study (Lima et al., 2006; Wang et al., 2011). Cantstain was shown to induce apoptosis through the induction of Fas-ligand, activation of procaspse8 and -9 cleavage, reduction in membrane potential, inhibition of Akt, FAK, mToR, eIF4E/4E-BP1 and ribosomal S6-kinase phosphorylations, in cultured HUVECs (Figure 2) (Panka and Mier, 2003). 


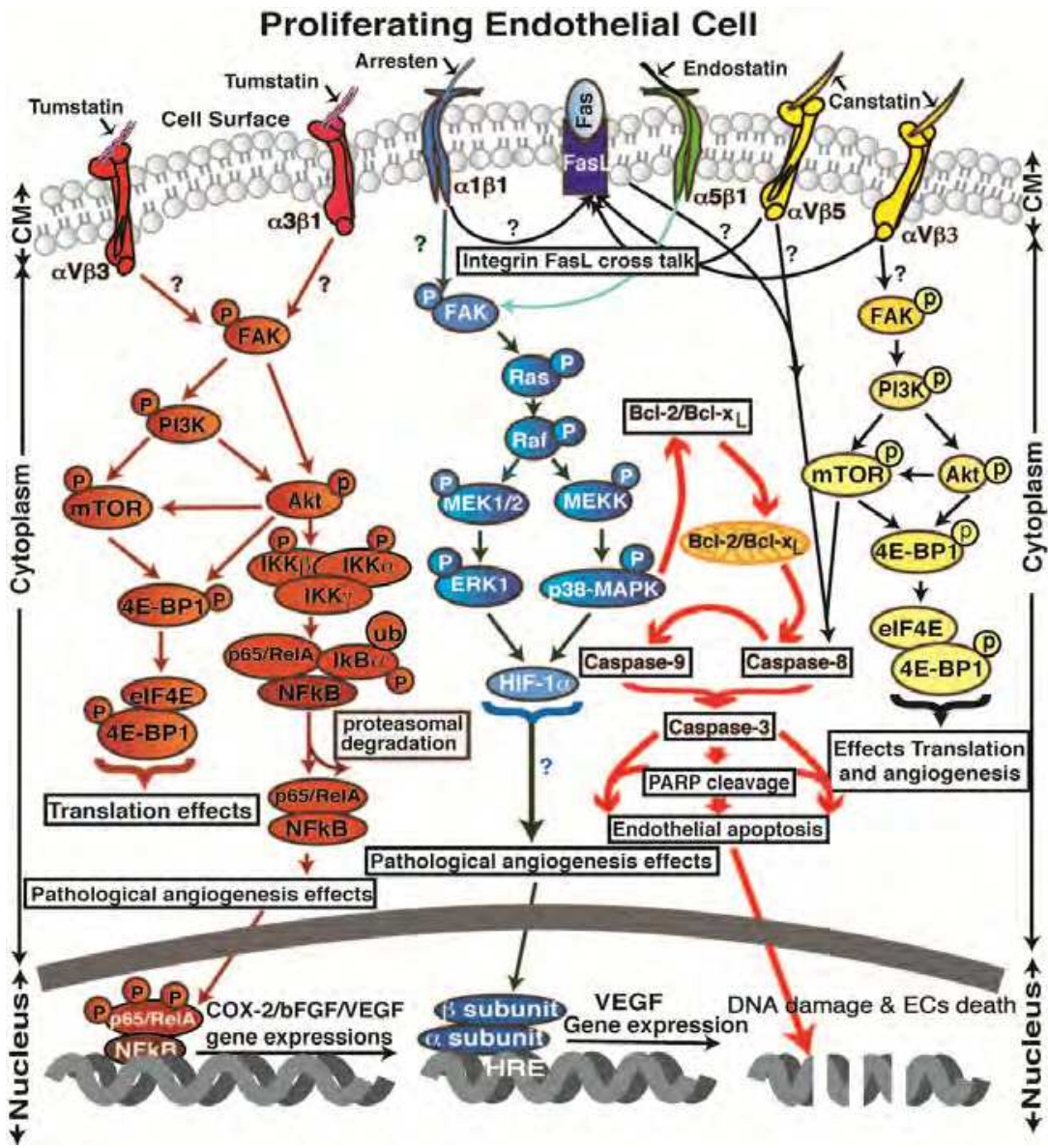

Fig. 2. Schematic illustration of distinct angioinhibitory signaling mediated by different extracellular matrix (ECM) reloaded molecules. Tumstatin, arresten, canstatin and endostatin interact with $\alpha \mathrm{V} \beta 3 / \alpha 3 \beta 1, \alpha 1 \beta 1, \alpha \mathrm{V} \beta 3 / \alpha \mathrm{V} \beta 5$ and $\alpha 5 \beta 1$ integrins respectively, to inhibit the phosphorylation of focal adhesion kinase (FAK). Tumstatin: It binds to $\alpha \mathrm{V} \beta 3$ and $\alpha 3 \beta 1$ integrins and inhibits the pathway that includes phosphorylation of FAK, PI3-K, Akt, mTOR, 4E-BP1 and eIF4E to decrease endothelial cell protein synthesis and proliferation. In addition tumstatin also inhibits NFKB mediated signaling in hypoxic conditions leading to the inhibition of COX-2, VEGF and bFGF expressions, resulting in inhibition of hypoxic tumor angiogenesis. Arresten: It binds to $\alpha 1 \beta 1$ integrin and inhibit phosphorylation FAK, causes inhibition of Ras, Raf, extra cellular signal related kinase 1 (ERK1) and p38 MAPK pathways that leads to inhibition of HIF- $1 \alpha$ and VEGF expression resulting in inhibition of endothelial cell migration, proliferation and tube formation. In addition arresten initiates two apoptotic pathways, involving activation of caspase- 9 and -8 , leading to activation of caspase-3 and PARP cleavage. (a) Arresten activates caspase- 3 directly through inhibition of FAK/p38-MAPK/Bcl-2/Bcl- $\mathrm{x}_{\mathrm{L}}$ and activation of caspase-9; (b) Integrin $\alpha 1 \beta 1$ cross talk with Fas-L through mitochondrial pathway and leads to activation of caspase- 8 and- 3 in 
proliferating endothelial cells. Canstatin: It binds to $\alpha \mathrm{V} \beta 3 / \alpha \mathrm{V} \beta 5$ integrins and inhibits two apoptotic pathways, involving activation of caspase- 8 and casoase-9, leading to activation of caspase-3. Canstatin activates procaspase-9 not only through inhibition of the FAK/PI3K/AKT pathways but also by integrins cross talking mitochondrial pathway through Fas-L dependent caspase- 8 activation leads to endothelial cell apoptosis. CM represents cell membrane. Endostatin: It binds to $\alpha 5 \beta 1$ integrin and inhibit phosphorylation FAK, causes inhibition of Ras, Raf, extra cellular signal related kinase-1 (ERK1) and p38 MAPK pathways that leads to inhibition of endothelial cell migration and tube formation.

\subsubsection{Tumstatin}

Tumstatin [ $\alpha 3(\mathrm{IV}) \mathrm{NC} 1]$, is a $28 \mathrm{kDa}$ collagen type IV, $\alpha 3$ chain derived non-collagenous domain with anti-angiogenic and proapoptotic activities. It binds to the CD47/IAP, $\alpha \mathrm{V} \beta 3$, $\alpha 3 \beta 1$ and $\alpha 6 \beta 1$ integrins and inhibits the signaling cascade mediated by FAK, Akt, PI3K/mTOR/eIF-4E/4E-BP1 and NFkB/COX-2 (Boosani et al., 2007; Hamano et al., 2003; Maeshima et al., 2002; Monboisse et al., 1994; Sudhakar et al., 2003). Inhibition of eIF-4E/4EBP1 by tumstatin leads to the regulation of cap dependent translational level of genes, whereas inhibition of transcriptional factor signaling such as NFKB leads to regulation of genes such as COX-2 at transcriptional level (Figure 2) (Boosani et al., 2007). Thus, tumstatin exhibits gene regulation in endothelail cell-specific and integrin-dependent manner. Angioinhibitory effect of tumstatin has been evaluated in regulation of CNV in mice (Boosani et al., 2011). Recombinant tumstatin regulated tube formation by mouse corneal endothelial cells (MCECs) in-vitro and adenoviral mediated expression of tumstatin in-vivo in mice has shown reduction in CNV (Boosani et al., 2011; Gunda et al., 2011).

\subsubsection{Endostatin}

Endostatin is the partial 20-kDa fragment of collagen type XVIII, carboxy terminal noncollagenous domain, derived from the parent collagen by proteolytic cleavage activities of elastase and cathepsin-L (Felbor et al., 2000). Endostatin is found in normal circulation enabling it to be utilized as an effective angioinhibitor without toxic effects (Fukai et al., 2002). Lower levels of endostatin have been recorded in CNV samples compared to the healthy donor eyes and within the tissues of progressive AMD (Bhutto et al., 2008; Fukai et al., 2002). Deletion of endostatin or collagen type XVIII massively up-regulates LASER induced $\mathrm{CNV}$; where as administration of physiological concentrations of endostatin was able to inhibit such CNV in these mice (Marneros et al., 2007). Endostatin also down regulates the expression of VEGF in experimental CNV rat models (Takahashi et al., 2003). These observations along with the evidence of inhibition of CNV with intravenous injection of adenoviral vectors that express secretable endostatin, confirm the significance of endostatin in regulation of CNV (Mori et al., 2001; Wickstrom et al., 2003).

Endostatin elicits the anti-proliferative and anti-migratory effects by binding to different EC surface molecules and regulating the signaling cascades (Faye et al., 2009). Recombinant endostatin binds to $\alpha \mathrm{V}$ integrin as shown in human endothelial cells (Rehn et al., 2001). Further studies have also shown localization of endostatin in the lipid rafts and association with caveolae (Wickstrom et al., 2002; Wickstrom et al., 2003). Surface plasmon resonance assays characterized the binding of endostatin to both $\alpha \mathrm{V} \beta 1$ integrins and the heparin 
sulfates and also localization to the lipid rafts (Ricard-Blum et al., 2004). In-vitro assays using ECs also showed the co-localization of endostatin with $\alpha 5 \beta 1$ integrin, actin stress fibers, membrane anchor protein and caveolin-1, which enumerates the interaction of endostatin with caveolae, inhibiting EC migration through the disassembly of actin stress fibers/focal adhesions, activation of Src and impaired fibronectin deposition by ECs in response to bFGF (Wickstrom et al., 2002; Wickstrom et al., 2003; Sudhakar et al., 2003). Binding of endostatin with integrins also down-regulates the activity of RhoA-GTPase and inhibits signaling pathways mediated by small kinases of the Ras and Raf families (Ricard-Blum et al., 2004). In addition, binding to the KDR/Flk-1, endostatin inhibits the VEGF-induced tyrosine phosphorylation of KDR/Flk-1 and activation of ERK, p38 MAPK, and p125FAK in HUVECs (Kim et al., 2002; Sudhakar et al., 2003). Further signaling cascades regulated by the endostatin are being identified, which are mediated by activator protein 1 (Id), HIF1 $\alpha$, ephrin, tumor necrosis factor- $\alpha(\mathrm{TNF} \alpha)$, nuclear factor- $\kappa \mathrm{B}(\mathrm{NF} \kappa \mathrm{B})$, coagulation cascades, adhesion molecules and Wnt, which indicate the potential role of endostatin as an endogenous angioinhibitor (Nyberg et al., 2005) (Figure 2).

\subsection{Scope for endogenous angioinhibitors in CNV treatment}

Current modalities of treatment for the CNV in AMD include the regulation of angiogenesis as angiogenesis being one of the pathological factors of neovascularization. The therapies such as LASER photocoagulation, photodynamic therapy and anti-VEGF therapies using Macugen or Lucentis, that are currently being applied to regulate the CNV have their own constraints such as development of lesions, loss of acuity in vision and frequent administration, respectively (Gallemore and Boyer, 2006). Alternative strategies for the treatment of $\mathrm{CNV}$ in AMD are therefore being developed in which the specific targeting on angiogenesis can be possible. Endogenous angioinhibitors are considered as one of the area to be explored in this arena to include them in regimens of complementary treatments for the regulation of CNV (Chappelow and Kaiser, 2008; Do, 2009). The signaling cascades regulated by some of endogenous angioinhibitors have been identified (Table 2 and Figure 2), which enabled the application of those inhibitors in CNV.

\section{Conclusions}

The cellular, extracellular milieu and genetic factors responsible for the neovascularization arising in AMD are being deciphered with emphasis on identifying those factors that play a key role in the inception and progression of CNV. In this scenario, different etiological factors have been identified which regulate angiogenesis, effecting both extracellular milieu and intracellular angiogenic signaling pathways. Identification of the signaling cascades leading to the pathological angiogenesis in CNV has further lead to the possibility of regulating $\mathrm{CNV}$, by focusing on signaling pathways as one of the targets. Application of endogenous angioinhibitors has proven as a promising strategy in this scenario of inhibiting angiogeneic pathways that are identified in CNV. The inhibitors such as vasoinhibins, PEDF, angiostatin, endostatin, tumstatin, canstatin and arresten that have been so far evaluated for regulation of $\mathrm{CNV}$ have not only shown promising evidence of $\mathrm{CNV}$ regulation, but also provided new strategies for inhibiting CNV through differential mode of actions. Such variation exhibited by different endogenous angioinhibitors can be beneficial in targeting $\mathrm{CNV}$ using different combinations of these inhibitors. It can be 
realized that these naturally occurring inhibitors can pose low immune reactions and thus, an efficient way of regulating diseases. Further, clinical studies using individual and combinations of endogenous angioinhibitors, included in different regimens along with current therapies of $\mathrm{CNV}$ would elaborate the application of endogenous angioinhibitors for regulating $\mathrm{CNV}$ of $\mathrm{AMD}$.

\section{Acknowledgements}

This study was supported by Flight Attendant Medical Research Institute Young Clinical Scientist Award Grant FAMRI-062558, NIH/NCI Grant RO1CA143128, Dobleman Head and Neck Cancer Institute Grant DHNCI-61905 and startup research funds of Cell Signaling, Retinal and Tumor Angiogenesis Laboratory at Boys Town National Research Hospital to YAS.

\section{References}

Alon, T., Hemo, I., Itin, A., Pe'er, J., Stone, J., and Keshet, E. (1995). Vascular endothelial growth factor acts as a survival factor for newly formed retinal vessels and has implications for retinopathy of prematurity. Nat Med 1, 1024-1028.

Apte, R. S., Barreiro, R. A., Duh, E., Volpert, O., and Ferguson, T. A. (2004). Stimulation of neovascularization by the anti-angiogenic factor PEDF. Invest Ophthalmol Vis Sci 45, 4491-4497.

Avraamides, C. J., Garmy-Susini, B., and Varner, J. A. (2008). Integrins in angiogenesis and lymphangiogenesis. Nat Rev Cancer 8, 604-617.

Bhutto, I. A., Uno, K., Merges, C., Zhang, L., McLeod, D. S., and Lutty, G. A. (2008). Reduction of endogenous angiogenesis inhibitors in Bruch's membrane of the submacular region in eyes with age-related macular degeneration. Arch Ophthalmol 126, 670-678.

Boosani, C. S., Gunda, V., Wang, S., Sheibani, N., and Sudhakar, A. Y. (2011). Tumstatin inhibits Choroidal Neovascularisation by Inhibiting MMP-2 activation in-vitro and in-vivo. Mol Vision. (Publication ahead of print).

Boosani, C. S., Mannam, A. P., Cosgrove, D., Silva, R., Hodivala-Dilke, K. M., Keshamouni, V. G., and Sudhakar, A. (2007). Regulation of COX-2 mediated signaling by alpha3 type IV noncollagenous domain in tumor angiogenesis. Blood 110, 1168-1177.

Boosani, C.S., Nalabothula, N., Munugalvadla, V., Cosgrove, D., Keshamouni, V. G., Sheibani, N., and Sudhakar, A. (2009). FAK and p38-MAP kinase-dependent activation of apoptosis and caspase-3 in retinal endothelial cells by $\alpha 1(\mathrm{IV}) \mathrm{NC1}$. Invest. Ophthalmol. Vis. Sci. 50, 4567-4575.

Boosani, C. S., Nalabothula, N., Sheibani, N., and Sudhakar, A. (2010). Inhibitory effects of arresten on bFGF-induced proliferation, migration, and matrix metalloproteinase-2 activation in mouse retinal endothelial cells. Curr Eye Res 35, 45-55.

Boosani, C. S., and Sudhakar, A. (2006). Cloning, purification, and characterization of a noncollagenous anti-angiogenic protein domain from human alpha1 type IV collagen expressed in Sf9 cells. Protein Expr Purif 49, 211-218. 
Bornstein, P. (2001). Thrombospondins as matricellular modulators of cell function. J Clin Invest 107, 929-934.

Bornstein, P. (2009). Thrombospondins function as regulators of angiogenesis. J Cell Commun Signal 3, 189-200.

Burwick, N. R., Wahl, M. L., Fang, J., Zhong, Z., Moser, T. L., Li, B., Capaldi, R. A., Kenan, D. J., and Pizzo, S. V. (2005). An Inhibitor of the F1 subunit of ATP synthase (IF1) modulates the activity of angiostatin on the endothelial cell surface. J Biol Chem 280, 1740-1745.

Cano Mdel, V., Karagiannis, E. D., Soliman, M., Bakir, B., Zhuang, W., Popel, A. S., and Gehlbach, P. L. (2009). A peptide derived from type 1 thrombospondin repeatcontaining protein WISP-1 inhibits corneal and choroidal neovascularization. Invest Ophthalmol Vis Sci 50, 3840-3845.

Carmeliet, P., and Jain, R. K. (2000). Angiogenesis in cancer and other diseases. Nature 407, 249-257.

Chan-Ling, T., Dahlstrom, J. E., Koina, M. E., McColm, J. R., Sterling, R. A., Bean, E. G., Adamson, S., Hughes, S., and Baxter, L. C. (2011). Evidence of hematopoietic differentiation, vasculogenesis and angiogenesis in the formation of human choroidal blood vessels. Exp Eye Res 92, 361-376.

Chappelow, A. V., and Kaiser, P. K. (2008). Neovascular age-related macular degeneration: potential therapies. Drugs 68, 1029-1036.

Clapp, C., Thebault, S., Arnold, E., Garcia, C., Rivera, J. C., and de la Escalera, G. M. (2008). Vasoinhibins: novel inhibitors of ocular angiogenesis. Am J Physiol Endocrinol Metab 295, E772-778.

Colorado, P. C., Torre, A., Kamphaus, G., Maeshima, Y., Hopfer, H., Takahashi, K., Volk, R., Zamborsky, E. D., Herman, S., Sarkar, P. K., Ericksen, M. B., Dhanabal, M., Simons, M., Post, M., Kufe, D. W., Weichselbaum, R. R., Sukhatme, V. P., and Kalluri, R. (2000). Anti-angiogenic cues from vascular basement membrane collagen. Cancer Res 60, 2520-2526.

D'Angelo, G., Struman, I., Martial, J., and Weiner, R. I. (1995). Activation of mitogenactivated protein kinases by vascular endothelial growth factor and basic fibroblast growth factor in capillary endothelial cells is inhibited by the antiangiogenic factor 16-kDa N-terminal fragment of prolactin. Proc Natl Acad Sci U S A 92, 6374-6378.

Dawson, D. W., Pearce, S. F., Zhong, R., Silverstein, R. L., Frazier, W. A., and Bouck, N. P. (1997). CD36 mediates the In vitro inhibitory effects of thrombospondin-1 on endothelial cells. J Cell Biol 138, 707-717.

Dejana, E. (2010). The role of wnt signaling in physiological and pathological angiogenesis. Circ Res 107, 943-952.

Do, D. V. (2009). Antiangiogenic approaches to age-related macular degeneration in the future. Ophthalmology 116, S24-26.

Dvorak, H. F., Brown, L. F., Detmar, M., and Dvorak, A. M. (1995). Vascular permeability factor/vascular endothelial growth factor, microvascular hyperpermeability, and angiogenesis. Am J Pathol 146, 1029-1039.

Egeblad, M., and Werb, Z. (2002). New functions for the matrix metalloproteinases in cancer progression. Nat Rev Cancer 2, 161-174. 
Faye, C., Moreau, C., Chautard, E., Jetne, R., Fukai, N., Ruggiero, F., Humphries, M. J., Olsen, B. R., and Ricard-Blum, S. (2009). Molecular interplay between endostatin, integrins, and heparan sulfate. J Biol Chem 284, 22029-22040.

Felbor, U., Dreier, L., Bryant, R. A., Ploegh, H. L., Olsen, B. R., and Mothes, W. (2000). Secreted cathepsin L generates endostatin from collagen XVIII. EMBO J 19, 11871194.

Fukai, N., Eklund, L., Marneros, A. G., Oh, S. P., Keene, D. R., Tamarkin, L., Niemela, M., Ilves, M., Li, E., Pihlajaniemi, T., and Olsen, B. R. (2002). Lack of collagen XVIII/endostatin results in eye abnormalities. EMBO J 21, 1535-1544.

Gallemore, P. R., and Boyer, D. S. (2006). PDT or Anti-VEGF for AMD treatment. Review of Ophthalmology online.

Gehlbach, P., Demetriades, A. M., Yamamoto, S., Deering, T., Duh, E. J., Yang, H. S., Cingolani, C., Lai, H., Wei, L., and Campochiaro, P. A. (2003). Periocular injection of an adenoviral vector encoding pigment epithelium-derived factor inhibits choroidal neovascularization. Gene Ther 10, 637-646.

Gonzalez, C., Corbacho, A. M., Eiserich, J. P., Garcia, C., Lopez-Barrera, F., Morales-Tlalpan, V., Barajas-Espinosa, A., Diaz-Munoz, M., Rubio, R., Lin, S. H., Martinez de la Escalera, G., and Clapp, C. (2004). 16K-prolactin inhibits activation of endothelial nitric oxide synthase, intracellular calcium mobilization, and endotheliumdependent vasorelaxation. Endocrinology 145, 5714-5722.

Green, W. R. (1999). Histopathology of age-related macular degeneration. Mol Vis 5, 27.

Green, W. R., and Enger, C. (1993). Age-related macular degeneration histopathologic studies. The 1992 Lorenz E. Zimmerman Lecture. Ophthalmology 100, 1519-1535.

Grossniklaus, H. E., Ling, J. X., Wallace, T. M., Dithmar, S., Lawson, D. H., Cohen, C., Elner, V. M., Elner, S. G., and Sternberg, P., Jr. (2002). Macrophage and retinal pigment epithelium expression of angiogenic cytokines in choroidal neovascularization. Mol Vis $8,119-126$.

Gunda, V., Wang, S., Sheibani, N., and Sudhakar, A. (2011). Inhibitory effect of tumstatin on corneal neovascularization both in-vitro and in-vivo. J Clinic Experment Ophthalmol (publication ahead of time).

Hamano, Y., Zeisberg, M., Sugimoto, H., Lively, J. C., Maeshima, Y., Yang, C., Hynes, R. O., Werb, Z., Sudhakar, A., and Kalluri, R. (2003). Physiological levels of tumstatin, a fragment of collagen IV alpha3 chain, are generated by MMP-9 proteolysis and suppress angiogenesis via alphaV beta3 integrin. Cancer Cell 3, 589-601.

Hayashi, M., Tamura, Y., Dohmae, N., Kojima, S., and Shimonaka, M. (2008). Plasminogen N-terminal activation peptide modulates the activity of angiostatin-related peptides on endothelial cell proliferation and migration. Biochem Biophys Res Commun 369, 635-640.

Hendricks, R. L. (2006). Interaction of angiogenic and immune mechanisms in the eye. Semin Ophthalmol 21, 37-40.

Ho, T. C., Chen, S. L., Yang, Y. C., Liao, C. L., Cheng, H. C., and Tsao, Y. P. (2007). PEDF induces p53-mediated apoptosis through PPAR gamma signaling in human umbilical vein endothelial cells. Cardiovasc Res 76, 213-223. 
Jager, R. D., Mieler, W. F., and Miller, J. W. (2008). Age-related macular degeneration. N Engl J Med 358, 2606-2617.

Kaur, S., Kuznetsova, S. A., Pendrak, M. L., Sipes, J. M., Romeo, M. J., Li, Z., Zhang, L., and Roberts, D. D. (2011). Heparan sulfate modification of the transmembrane receptor CD47 is necessary for inhibition of T cell receptor signaling by thrombospondin-1. J Biol Chem 286, 14991-15002.

Kim, Y. M., Hwang, S., Pyun, B. J., Kim, T. Y., Lee, S. T., Gho, Y. S., and Kwon, Y. G. (2002). Endostatin blocks vascular endothelial growth factor-mediated signaling via direct interaction with KDR/Flk-1. J Biol Chem 277, 27872-27879.

Lai, C. C., Wu, W. C., Chen, S. L., Xiao, X., Tsai, T. C., Huan, S. J., Chen, T. L., Tsai, R. J., and Tsao, Y. P. (2001). Suppression of choroidal neovascularization by adeno-associated virus vector expressing angiostatin. Invest Ophthalmol Vis Sci 42, 2401-2407.

Lawler, J. (2000). The functions of thrombospondin-1 and-2. Curr Opin Cell Biol 12, 634-640.

Lima, E. S. R., Kachi, S., Akiyama, H., Shen, J., Aslam, S., Yuan Gong, Y., Khu, N. H., Hatara, M. C., Boutaud, A., Peterson, R., and Campochiaro, P. A. (2006). Recombinant noncollagenous domain of alpha2(IV) collagen causes involution of choroidal neovascularization by inducing apoptosis. J Cell Physiol 208, 161-166.

Lu, M., and Adamis, A. P. (2006). Molecular biology of choroidal neovascularization. Ophthalmol Clin North Am 19, 323-334.

Maeshima, Y., Colorado, P. C., Torre, A., Holthaus, K. A., Grunkemeyer, J. A., Ericksen, M. B., Hopfer, H., Xiao, Y., Stillman, I. E., and Kalluri, R. (2000). Distinct antitumor properties of a type IV collagen domain derived from basement membrane. J Biol Chem 275, 21340-21348.

Maeshima, Y., Sudhakar, A., Lively, J. C., Ueki, K., Kharbanda, S., Kahn, C. R., Sonenberg, N., Hynes, R. O., and Kalluri, R. (2002). Tumstatin, an endothelial cell-specific inhibitor of protein synthesis. Science 295, 140-143.

Magnon, C., Galaup, A., Mullan, B., Rouffiac, V., Bouquet, C., Bidart, J. M., Griscelli, F., Opolon, P., and Perricaudet, M. (2005). Canstatin acts on endothelial and tumor cells via mitochondrial damage initiated through interaction with alphavbeta3 and alphavbeta5 integrins. Cancer Res 65, 4353-4361.

Magnon, C., Opolon, P., Ricard, M., Connault, E., Ardouin, P., Galaup, A., Metivier, D., Bidart, J. M., Germain, S., Perricaudet, M., and Schlumberger, M. (2007). Radiation and inhibition of angiogenesis by canstatin synergize to induce HIF-1alphamediated tumor apoptotic switch. J Clin Invest 117, 1844-1855.

Marneros, A. G., She, H., Zambarakji, H., Hashizume, H., Connolly, E. J., Kim, I., Gragoudas, E. S., Miller, J. W., and Olsen, B. R. (2007). Endogenous endostatin inhibits choroidal neovascularization. FASEB J 21, 3809-3818.

Marshall, J. (1987). The ageing retina: physiology or pathology. Eye (Lond) 1 ( Pt 2), 282-295.

Martini, J. F., Piot, C., Humeau, L. M., Struman, I., Martial, J. A., and Weiner, R. I. (2000). The antiangiogenic factor 16K PRL induces programmed cell death in endothelial cells by caspase activation. Mol Endocrinol 14, 1536-1549.

Mettouchi, A., and Meneguzzi, G. (2006). Distinct roles of beta1 integrins during angiogenesis. Eur J Cell Biol 85, 243-247. 
Miyajima-Uchida, H., Hayashi, H., Beppu, R., Kuroki, M., Fukami, M., Arakawa, F., Tomita, Y., and Oshima, K. (2000). Production and accumulation of thrombospondin-1 in human retinal pigment epithelial cells. Invest Ophthalmol Vis Sci 41, 561-567.

Monboisse, J. C., Garnotel, R., Bellon, G., Ohno, N., Perreau, C., Borel, J. P., and Kefalides, N. A. (1994). The alpha 3 chain of type IV collagen prevents activation of human polymorphonuclear leukocytes. J Biol Chem 269, 25475-25482.

Mori, K., Ando, A., Gehlbach, P., Nesbitt, D., Takahashi, K., Goldsteen, D., Penn, M., Chen, C. T., Melia, M., Phipps, S., Moffat, D., Brazzell, K., Liau, G., Dixon, K. H., and Campochiaro, P. A. (2001). Inhibition of choroidal neovascularization by intravenous injection of adenoviral vectors expressing secretable endostatin. Am J Pathol 159, 313-320.

Nozaki, M., Raisler, B. J., Sakurai, E., Sarma, J. V., Barnum, S. R., Lambris, J. D., Chen, Y., Zhang, K., Ambati, B. K., Baffi, J. Z., and Ambati, J. (2006). Drusen complement components $\mathrm{C} 3 \mathrm{a}$ and $\mathrm{C} 5 \mathrm{a}$ promote choroidal neovascularization. Proc Natl Acad Sci US A 103, 2328-2333.

Nyberg, P., Xie, L., and Kalluri, R. (2005). Endogenous inhibitors of angiogenesis. Cancer Res 65, 3967-3979.

Oklu, R., Walker, T. G., Wicky, S., and Hesketh, R. (2010). Angiogenesis and current antiangiogenic strategies for the treatment of cancer. J Vasc Interv Radiol 21, 17911805; quiz 1806.

Panka, D. J., and Mier, J. W. (2003). Canstatin inhibits Akt activation and induces Fasdependent apoptosis in endothelial cells. J Biol Chem 278, 37632-37636.

Penn, J. S., Madan, A., Caldwell, R. B., Bartoli, M., Caldwell, R. W., and Hartnett, M. E. (2008). Vascular endothelial growth factor in eye disease. Prog Retin Eye Res 27, 331-371.

Petitclerc, E., Boutaud, A., Prestayko, A., Xu, J., Sado, Y., Ninomiya, Y., Sarras, M. P., Jr., Hudson, B. G., and Brooks, P. C. (2000). New Functions for Non-collagenous Domains of Human Collagen Type IV. Novel integrin ligands inhibiting angiogenesis and tumor growth in vivo. J Biol Chem 275, 8051-8061.

Rehn, M., Veikkola, T., Kukk-Valdre, E., Nakamura, H., Ilmonen, M., Lombardo, C., Pihlajaniemi, T., Alitalo, K., and Vuori, K. (2001). Interaction of endostatin with integrins implicated in angiogenesis. Proc Natl Acad Sci U S A 98, 1024-1029.

Ricard-Blum, S., Feraud, O., Lortat-Jacob, H., Rencurosi, A., Fukai, N., Dkhissi, F., Vittet, D., Imberty, A., Olsen, B. R., and van der Rest, M. (2004). Characterization of endostatin binding to heparin and heparan sulfate by surface plasmon resonance and molecular modeling: role of divalent cations. J Biol Chem 279, 2927-2936.

Roberts, W. G., and Palade, G. E. (1995). Increased microvascular permeability and endothelial fenestration induced by vascular endothelial growth factor. J Cell Sci 108 ( Pt 6), 2369-2379.

Roth, J. M., Akalu, A., Zelmanovich, A., Policarpio, D., Ng, B., MacDonald, S., Formenti, S., Liebes, L., and Brooks, P. C. (2005). Recombinant alpha2(IV)NC1 domain inhibits tumor cell-extracellular matrix interactions, induces cellular senescence, and inhibits tumor growth in vivo. Am J Pathol 166, 901-911. 
Spaide, R. F., Armstrong, D., and Browne, R. (2003). Continuing medical education review: choroidal neovascularization in age-related macular degeneration--what is the cause? Retina 23, 595-614.

Sudhakar, A., and Boosani, C. S. (2008). Inhibition of tumor angiogenesis by tumstatin: insights into signaling mechanisms and implications in cancer regression. Pharm Res 25, 2731-2739.

Sudhakar, A., and Kalluri, R. (2010). Molecular mechanisms of angiostatis. Encyclopedia of the eye $3 M-P, 52-59$.

Sudhakar, A., Nyberg, P., Keshamouni, V. G., Mannam, A. P., Li, J., Sugimoto, H., Cosgrove, D., and Kalluri, R. (2005). Human alpha1 type IV collagen NC1 domain exhibits distinct antiangiogenic activity mediated by alpha1beta1 integrin. J Clin Invest 115, 2801-2810.

Sudhakar, A., Sugimoto, H., Yang, C., Lively, J., Zeisberg, M., and Kalluri, R. (2003). Human tumstatin and human endostatin exhibit distinct antiangiogenic activities mediated by alpha vbeta 3 and alpha 5beta 1 integrins. Proc Natl Acad Sci U S A 100, 47664771.

Tabruyn, S. P., Sorlet, C. M., Rentier-Delrue, F., Bours, V., Weiner, R. I., Martial, J. A., and Struman, I. (2003). The antiangiogenic factor 16K human prolactin induces caspasedependent apoptosis by a mechanism that requires activation of nuclear factorkappaB. Mol Endocrinol 17, 1815-1823.

Takahashi, K., Saishin, Y., Silva, R. L., Oshima, Y., Oshima, S., Melia, M., Paszkiet, B., Zerby, D., Kadan, M. J., Liau, G., Kaleko, M., Connelly, S., Luo, T., and Campochiaro, P. A. (2003). Intraocular expression of endostatin reduces VEGF-induced retinal vascular permeability, neovascularization, and retinal detachment. FASEB J 17, 896-898.

Tarui, T., Miles, L. A., and Takada, Y. (2001). Specific interaction of angiostatin with integrin alpha(v)beta(3) in endothelial cells. J Biol Chem 276, 39562-39568.

Tombran-Tink, J., Chader, G. G., and Johnson, L. V. (1991). PEDF: a pigment epitheliumderived factor with potent neuronal differentiative activity. Exp Eye Res 53, 411414.

Wang, Y., Yin, H., Chen, P., and Xie, L. (2011). Inhibitory Effect of Canstatin in Alkali BurnInduced Corneal Neovascularization. Ophthalmic Res 46, 66-72.

Wickstrom, S. A., Alitalo, K., and Keski-Oja, J. (2002). Endostatin associates with integrin alpha5beta1 and caveolin-1, and activates Src via a tyrosyl phosphatase-dependent pathway in human endothelial cells. Cancer Res 62, 5580-5589.

Wickstrom, S. A., Alitalo, K., and Keski-Oja, J. (2003). Endostatin associates with lipid rafts and induces reorganization of the actin cytoskeleton via down-regulation of RhoA activity. J Biol Chem 278, 37895-37901.

Young, R. W., and Bok, D. (1969). Participation of the retinal pigment epithelium in the rod outer segment renewal process. J Cell Biol 42, 392-403.

Zerlin, M., Julius, M. A., and Kitajewski, J. (2008). Wnt/Frizzled signaling in angiogenesis. Angiogenesis 11, 63-69.

Zhang, S. X., and Ma, J. X. (2007). Ocular neovascularization: Implication of endogenous angiogenic inhibitors and potential therapy. Prog Retin Eye Res 26, 1-37. 
Zhou, S. Y., Xie, Z. L., Xiao, O., Yang, X. R., Heng, B. C., and Sato, Y. (2010). Inhibition of mouse alkali burn induced-corneal neovascularization by recombinant adenovirus encoding human vasohibin-1. Mol Vis 16, 1389-1398.

Zhou, X. Y., Liao, Q., Pu, Y. M., Tang, Y. Q., Gong, X., Li, J., Xu, Y., and Wang, Z. G. (2009). Ultrasound-mediated microbubble delivery of pigment epithelium-derived factor gene into retina inhibits choroidal neovascularization. Chin Med J (Engl) 122, 27112717.

Ziche, M., and Morbidelli, L. (2000). Nitric oxide and angiogenesis. J Neurooncol 50, 139-148. 


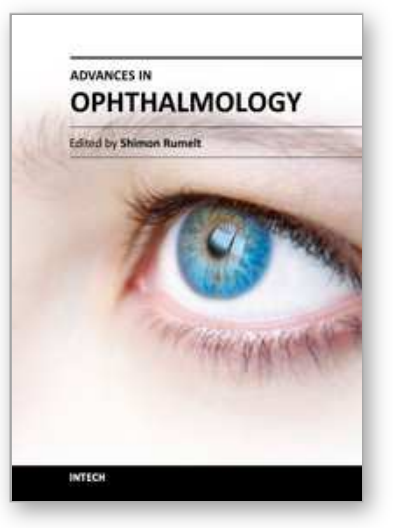

\author{
Advances in Ophthalmology \\ Edited by Dr Shimon Rumelt
}

ISBN 978-953-51-0248-9

Hard cover, 568 pages

Publisher InTech

Published online 07, March, 2012

Published in print edition March, 2012

This book focuses on the different aspects of ophthalmology - the medical science of diagnosis and treatment of eye disorders. Ophthalmology is divided into various clinical subspecialties, such as cornea, cataract, glaucoma, uveitis, retina, neuro-ophthalmology, pediatric ophthalmology, oncology, pathology, and oculoplastics. This book incorporates new developments as well as future perspectives in ophthalmology and is a balanced product between covering a wide range of diseases and expedited publication. It is intended to be the appetizer for other books to follow. Ophthalmologists, researchers, specialists, trainees, and general practitioners with an interest in ophthalmology will find this book interesting and useful.

\title{
How to reference
}

In order to correctly reference this scholarly work, feel free to copy and paste the following:

Venugopal Gunda and Yakkanti A. Sudhakar (2012). Regulation of Angiogenesis in Choroidal Neovascularization of Age Related Macular Degeneration by Endogenous Angioinhibitors, Advances in Ophthalmology, Dr Shimon Rumelt (Ed.), ISBN: 978-953-51-0248-9, InTech, Available from: http://www.intechopen.com/books/advances-in-ophthalmology/regulation-of-angiogenesis-in-choroidalneovascularization-of-age-related-macular-degeneration-by-en

\section{INTECH}

open science | open minds

\section{InTech Europe}

University Campus STeP Ri

Slavka Krautzeka 83/A

51000 Rijeka, Croatia

Phone: +385 (51) 770447

Fax: +385 (51) 686166

www.intechopen.com

\section{InTech China}

Unit 405, Office Block, Hotel Equatorial Shanghai

No.65, Yan An Road (West), Shanghai, 200040, China

中国上海市延安西路65号上海国际贵都大饭店办公楼 405 单元

Phone: +86-21-62489820

Fax: $+86-21-62489821$ 
(C) 2012 The Author(s). Licensee IntechOpen. This is an open access article distributed under the terms of the Creative Commons Attribution 3.0 License, which permits unrestricted use, distribution, and reproduction in any medium, provided the original work is properly cited. 